\title{
Hysterosalpingography: Balloon Catheter or Metal Cannula?
}

\author{
Participants: \\ (iD) Antonio Silvinato ${ }^{1}$ \\ Wanderley Marques Bernardo ${ }^{1,2}$ \\ Created on: 04 June, 2019 \\ 1. Programa Diretrizes - Associação Médica Brasileira, São Paulo, SP, Brasil \\ 2. Coordenador do Programa Diretrizes da Associação Médica Brasileira, São Paulo, SP, Brasil \\ E-mail:wmbernardo@usp.br
}

http://dx.doi.org/10.1590/1806-9282.66.3.252

The Guidelines Project, an initiative of the Brazilian Medical Association, aims to combine information from the medical field in order to standardize producers to assist the reasoning and decision-making of doctors.

The information provided through this project must be assessed and criticized by the physician responsible for the conduct that will be adopted, depending on the conditions and the clinical status of each patient.

\section{INTRODUCTION}

Hysterosalpingography (HSG) is a traditional method widely used in basic infertility diagnostic assessment. Tubular factors alone account for $14 \%$ of subfertility causes. HSG is recommended to assess fallopian tube permeability in the absence of comorbidities. Compared with laparoscopy, it is less invasive and has a lower cost. Hysteroscopy is recognized as the gold standard exam to identify uterine abnormalities because it allows direct visualization of the uterine cavity.

HSG defines the contour and the size of the uterine cavity, cervical canal, and allows the visualization of the bilateral tube filling. Unfortunately, HSG is widely known as a painful procedure, with pain affecting all women who undergo the procedure. Recent studies have reported several techniques developed to improve not only the quality of the uterine cavity and tubal passage imaging but also patient comfort.

Several balloon catheters, vacuum cannulas, and traditional metal cannulas have bee compared to determine the best procedure for patients.

\section{OBJECTIVE}

The goal of this assessment is to compare the metal cannula routinely used in clinical practice with the hysterosalpingography intrauterine balloon catheter as a possible alternate device.

\section{METHODS}

The clinical question is: "Is the use of a hysterosalpingography (HSG) intrauterine balloon catheter safe and effective in comparison with a metal cannula?"

The eligibility criteria for the studies are:

1. Adult patients with an indication for hysterosalpingography. 
2. Use of a balloon catheter compared to a metal cannula.

3. Outcomes: pain during the procedure, complication rates, and reinsertion.

4. Intermediate outcomes such as satisfaction with the treatment, fluoroscopy time, and volume of contrast were excluded.

5. Randomized clinical trial.

6. No time or language restrictions.

7. Full text available for access.

The search for evidence was conducted in two virtual databases of scientific information: Medline, using the following as search strategy: Hysterosalpingography AND (Balloon Catheter) AND (metal cannula OR Metals); and Central (Cochrane), with a search for Hysterosalpingography AND (Balloon Catheter) AND (metal cannula).

We extracted the following data from the studies: name of the author and year of publication, study population, intervention and comparison methods, the absolute number of adverse events, average pain score (SD), and follow-up time.

Randomized clinical trials had their risk of biases analyzed according to the following criteria: randomization, blinded allocation, double-blinding, losses, prognostic characteristics, presence of relevant outcome, time for the outcome, the method for outcome measurement, sample size calculation, early interruption, presence of other biases.

The results were expressed by the difference in the risk of adverse events and the difference in the mean pain score between the balloon catheter and the metal cannula for HSG. The confidence level adopted was $95 \%$.

Furthermore, the quality of evidence was graded as strong, moderate, low, or very low using the Grade instrument ${ }^{(1)}$ and taking into account the risk of bias, the presence of inconsistency, imprecision, or indirect evidence in the outcomes of pain reduction and adverse events, and the presence of publication bias.

\section{RESULTS}

The search for evidence retrieved seven studies, of which four were selected based on their titles and abstracts comparing balloon-catheter versus metal cannula in HSG. Since all four met the eligibility criteria, their full texts were accessed for analysis. Of the four studies selected to support this assessment, only three were included since one of them used a Foley catheter as the balloon catheter(Figure 1).

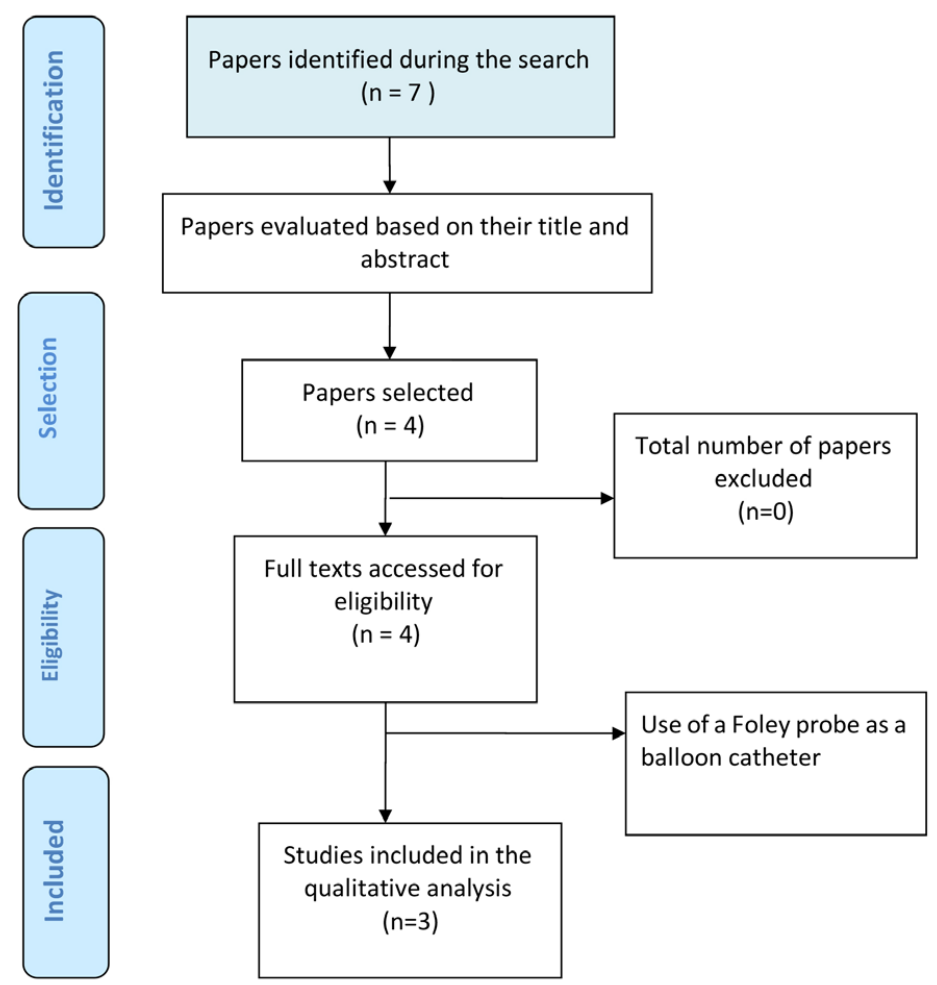


The population included comprises 258 patients who underwent HSG for evaluation of tubal permeability, without anesthetic block, using a balloon catheter $(\mathrm{N}=143)$ or metal cannula $(\mathrm{N}=115)$ and followed-up to measure the outcome of pain during the procedure or up to one hour after it and adverse events (Table 1).

Regarding the risk of biases of the three studies included, only one describes the randomization and allocation process; none of them is double-blind, and only one calculated the sample size; thus, the overall risk of the studies can be considered moderate (Table 2).

Two studies ${ }^{(3.4)}$ assessed the pain during the procedure, but one of them ${ }^{(3)}$ does not report the standard deviation, which prevents the pooling of results. These two studies also assessed pain during the injection of contrast medium, using different measures (VAS scores and percentage of patients in pain, uncomfortable, or without pain), making grouping impossible. (Table 3 and 4)

All three studies ${ }^{(2-4)}$ included in this evaluation show a reduction of pain during the procedure with the use of a balloon catheter in comparison with the metal cannula. One of them shows that this reduction was maintained until one hour after the $\mathrm{HSG}^{(2)}$. The most frequent adverse events were nausea and need for reapplication and both were reduced with the use of a balloon catheter. However, there was no statistical difference regarding reapplication in comparison ${ }^{(2)}$.

TABLE 1. HYSTEROSALPINGOGRAPHY - BALLOON CATHETER VS. METAL CANNULA - DESCRIPTION OF THE STUDIES INCLUDED.

\begin{tabular}{l|l|l|l|l} 
STUDY & POPULATION & INTERVENTION (N) & COMPARISON (N) & TIME \\
\hline $\begin{array}{l}\text { Kiykac Altinbas S, 2015 } \\
\begin{array}{l}\text { de Mello JF Sr, } \\
2006\end{array}\end{array}$ & HSG & Balloon catheter (83) & Metal cannula (85) & $\begin{array}{l}\text { During and 1 hour after the } \\
\text { procedure }\end{array}$ \\
\hline $\begin{array}{l}\text { Tur-Kaspa I, } \\
1998\end{array}$ & HSG & Balloon catheter (30) & $\begin{array}{l}\text { 1. Metal cannula without anes- } \\
\text { thesia (30) } \\
\text { the procedure } \\
\text { 2. Metal cannula with paracer- } \\
\text { vical block anesthesia (29) - Not } \\
\text { compared in this assessment }\end{array}$ & $\begin{array}{l}\text { Metal cannula (31) } \\
\text { the procedure }\end{array}$ \\
\hline
\end{tabular}

TABLE 2. HSG - BALLOON CATHETER VS. METAL CANNULA - RISK OF BIASES OF THE STUDIES INCLUDED

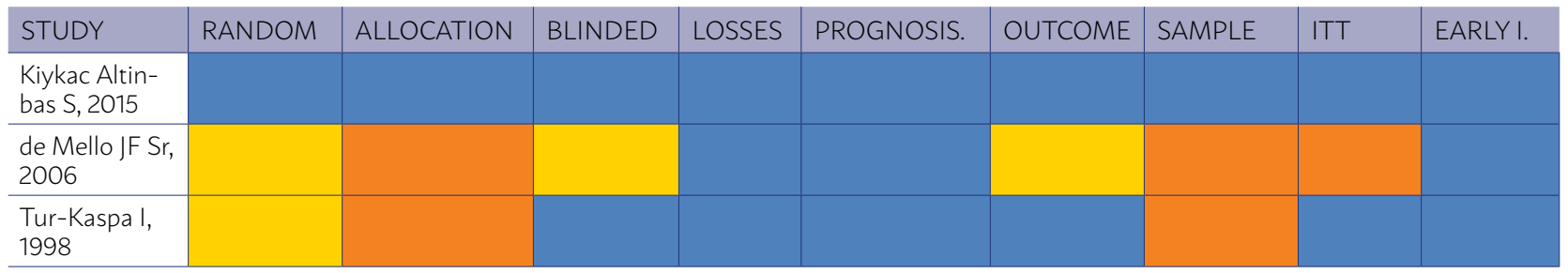

(orange = presence; blue = absence; yellow = unclear - risk of bias). ITT = intention-to-treat analysis.

TABLE 3. HSG - BALLOON CATHETER VS. METAL CANNULA - RESULTS OF THE STUDIES INCLUDED MEASUREMENT OF PAIN DURING THE PROCEDURE.

\begin{tabular}{|c|c|c|c|c|c|}
\hline STUDY & MOMENT OF PAIN & BALLOON CATHETER & METAL CANNULA & $\mathrm{MD}(95 \% \mathrm{Cl})$ & $\mathrm{p}$ \\
\hline \multirow{3}{*}{$\begin{array}{l}\text { Kiykac Altinbas S(2), } \\
2015\end{array}$} & During device placement & ${ }^{*} 2.11 \pm 0.87$ (VAS) & ${ }^{*} 2.51 \pm 1.07$ (VAS) & $-0.4(-0.69$ to -0.10 & 0.008 \\
\hline & During contrast injection & *2.63 \pm 0.93 & *3.74 \pm 0.91 & $-1.11(-1.39 a-0.82)$ & $<0.00001$ \\
\hline & 1 hour after & ${ }^{\star} 2.13 \pm 1.18$ & *3.07 \pm 1.02 & $-0.94(-1.27$ to -0.60 & $<0.00001$ \\
\hline $\begin{array}{l}\text { de Mello JF Sr }{ }^{(3)} \text {, } \\
2006\end{array}$ & $\begin{array}{l}\text { Pain during the } \\
\text { procedure }\end{array}$ & $4.3 \pm ?$ (VAS) & $6.8 \pm ?($ VAS $)$ & -2.25 & $<0.05$ \\
\hline Tur-Kaspa I(4), 1998 & Pain during the procedure & $3.8 \pm 2$ (VAS) & $5.6 \pm 2$ (VAS) & $-1.8(-2.8$ to -0.77$)$ & 0.0008 \\
\hline
\end{tabular}

*The Wong-Baker Faces Pain Rating Scale (WBS) goes from 0 to 5 - there is an agreement between the facial pain assessment scale and the visual analog score (VAS); ? = not reported; $\mathrm{MD}=$ mean difference; $\mathrm{Cl}=$ confidence interval. 
TABLE 4. HSG - BALLOON CATHETER VS. METAL CANNULA RESULTS OF THE STUDIES INCLUDED MEASUREMENT OF ADVERSE EVENTS

\begin{tabular}{|c|c|c|c|c|c|}
\hline STUDY & ADVERSE EVENT & BALLOON CATHETER & METAL CANNULA & $\operatorname{ARR}(95 \% \mathrm{Cl})$ & NNT $(95 \% \mathrm{Cl})$ \\
\hline \multirow[t]{2}{*}{ Kiykac Altinbas S(2),2015 } & Nausea & $1 \operatorname{pac}(1.2 \%)$ & $12 \operatorname{pac}(14.1 \%)$ & $12.9 \%$ (0.051 to 0.125$)$ & $8(5$ a 9$)$ \\
\hline & Reapplication & $2 \operatorname{pac}(2.4 \%)$ & 7 pac (8.2\%) & $5.8 \%(-0.009$ to 0.125$)$ & NS \\
\hline de Mello JF Sr(3),2006 & Not reported & - & - & - & - \\
\hline Tur-Kaspa |(4), 1998 & No adverse events & 0 & 0 & - & - \\
\hline
\end{tabular}

$\mathrm{ARR}=$ absolute risk reduction; NNT = number needed to treat.

TABLE 5. ANALYSIS OF THE QUALITY OF EVIDENCE (GRADE PRO SOFTWARE)(1)

\begin{tabular}{|c|c|c|c|c|c|c|c|c|c|c|c|c|}
\hline \multicolumn{7}{|c|}{ EVALUATION OF CERTAINTY } & \multicolumn{2}{|c|}{ \# of patients } & \multicolumn{2}{|l|}{ Effect } & \multirow{2}{*}{$\begin{array}{l}\text { CER- } \\
\text { TAINTY }\end{array}$} & \multirow{2}{*}{$\begin{array}{l}\text { Impor- } \\
\text { tance }\end{array}$} \\
\hline $\begin{array}{l}\text { No of } \\
\text { stud- } \\
\text { ies }\end{array}$ & $\begin{array}{l}\text { De- } \\
\text { sign } \\
\text { of the } \\
\text { study }\end{array}$ & $\begin{array}{l}\text { Risk of } \\
\text { bias }\end{array}$ & $\begin{array}{l}\text { Incon- } \\
\text { sisten- } \\
\text { cy }\end{array}$ & $\begin{array}{l}\text { Indirect } \\
\text { evidence }\end{array}$ & $\begin{array}{l}\text { Impre- } \\
\text { cision }\end{array}$ & $\begin{array}{l}\text { Other } \\
\text { con- } \\
\text { sider- } \\
\text { ations }\end{array}$ & $\begin{array}{l}\text { HSG with } \\
\text { balloon } \\
\text { catheter }\end{array}$ & $\begin{array}{l}\text { HSG } \\
\text { with } \\
\text { metal } \\
\text { cannula }\end{array}$ & $\begin{array}{l}\text { Relative } \\
(95 \% \\
\mathrm{CI})\end{array}$ & $\begin{array}{l}\text { Absolute } \\
(95 \% \mathrm{Cl})\end{array}$ & & \\
\hline \multicolumn{13}{|c|}{ Pain during device placement } \\
\hline 1 & $\begin{array}{l}\text { ran- } \\
\text { dom- } \\
\text { ized } \\
\text { clinical } \\
\text { trial }\end{array}$ & $\begin{array}{l}\text { not } \\
\text { severe }\end{array}$ & $\begin{array}{l}\text { not } \\
\text { severe }\end{array}$ & not severe & $\begin{array}{l}\text { not } \\
\text { severe }\end{array}$ & None & 83 & 85 & - & $\begin{array}{l}\text { MD } 0.4 \\
\text { lower } \\
\text { (0.69 } \\
\text { lower for } \\
\text { O.1 lower) }\end{array}$ & $\begin{array}{l}\oplus \oplus \oplus \oplus \\
\mathrm{HIGH}\end{array}$ & $\begin{array}{l}\text { IM- } \\
\text { PORT- } \\
\text { ANT }\end{array}$ \\
\hline
\end{tabular}

Cl: confidence interval; MD: mean difference.

\section{QUALITY OF EVIDENCE FOR THE OUTCOME OF PAIN DURING DEVICE PLACEMENT}

One study evaluated this outcome $\mathrm{e}^{(2)}$.

Question: Does the use of a balloon-catheter in HSG, in comparison with the use of a metal cannula, for basic infertility diagnostic evaluation reduce pain during device placement? (Table 5)

\section{SYNTHESIS OF EVIDENCE}

In patients submitted to HSG, the use of a balloon catheter, in comparison with a metal cannula, reduces pain during the procedure and up to one hour after it and can also reduce nausea. The quality of the evidence that supports this result is high.

\section{REFERENCES}

1. GRADEpro GDT: GRADEpro Guideline Development Tool [Software]. McMaster University, 2015 (developed by Evidence Prime, Inc.). Available from gradepro.org.

2. Kiykac Altinbas S, Dilbaz B, Zengin T, Kilic S, Cakir L, Sengul O, et al. Evaluation of pain during hysterosalpingography with the use of balloon catheter vs metal cannula. J Obstet Gynaecol 2015;35:193-8. PMID: 25141095

3. de Mello JF Sr, Abrao MS, Cerri GG, de Barros N. Evaluation of pain in three hysterosalpingography techniques: metal cannula with and without paracervical blockage and balloon catheter. AJR Am J Roentgenol 2006;187:86-9. PMID: 16794160

4. Tur-Kaspa I, Seidman DS, Soriano D, Greenberg I, Dor |, Bider D. Hysterosalpingography with a balloon catheter versus a metal cannula: a prospective, randomized, blinded comparative study. Hum Reprod 1998;13:75-7. PMID: 9512232

Studies excluded and reason

1. Varpula M. Hysterosalpingography with a balloon catheter versus a cannula: evaluation of patient pain. Radiology. 1989;172:745-7. PMID: 2772182. THE BALLOON CATHETER USED WAS A PEDIATRIC FOLEY CATHETER No. 8 